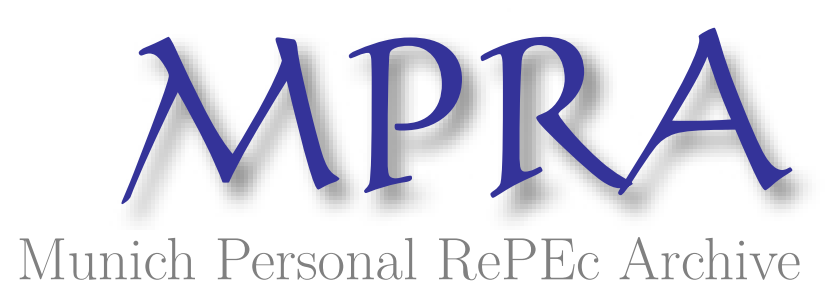

\title{
Wage spillovers across sectors in Eastern Europe
}

\author{
D'Adamo, Gaetano
}

Università di Bologna

3 January 2011

Online at https://mpra.ub.uni-muenchen.de/27841/

MPRA Paper No. 27841, posted 03 Jan 2011 19:42 UTC 


\title{
Wage spillovers across sectors in Eastern Europe
}

\author{
Gaetano D'Adamo* \\ This Draft: December $2^{\text {nd }} 2010$ \\ $\sim$ Preliminary and incomplete draft. Comments are welcome
}

\begin{abstract}
This paper studies the interactions between wages in the public sector, the traded private sector and the sheltered private sector in ten EU Transition Countries and its relationship to international competitiveness during the decade 2000-2010. The theoretical literature on wage spillovers suggests that the internationally traded sector should be the leader in wage setting, with sheltered and public sector (the non-traded sector) wages adjusting. Using a Cointegrated VAR approach we show that a large heterogeneity across countries is present, with non-traded sectors wages often being leaders in wage determination or at least affecting traded sector wages in the short run. In some countries, public sector wages are weakly exogenous, with the private sectors adjusting. This result is relevant from a policy perspective since wage spillovers, leading to costs growing faster than productivity, may affect the international cost competitiveness of the traded sector.
\end{abstract}

JEL Classification: C32; E62; J31

Keywords: Cointegrated VAR, wage setting, public sector.

\footnotetext{
* I thank Riccardo Rovelli and participants at the XXXVII Macromodels International Conference and in Seminars at the University of Bologna for enlightening comments.

Correspondance address: Dipartimento di Scienze Economiche, Università di Bologna - Piazza Scaravilli, 140126 Bologna. E-mail: gaetano.dadamo3@unibo.it. Office phone number: (+39) 0512092641
} 


\section{Introduction}

The aim of this paper is to study the interactions and spillovers between wages in different sectors. In particular, we analyze the interplay in wage determination in three broad sectors: the open (internationally traded) sector, the closed or "sheltered sector", which can also be called the market non-traded sector, and the public sector, also called the non-market non-traded sector. The focus of this work is on Central and Eastern European Countries (CEEC) that have recently joined the European Union.

This issue is relevant for several reasons. First, public sector employment is large and relevant: in the OECD, around $25 \%$ of the work force is employed in the public sector. Second, wage spillovers across sectors may lead to wage costs growing faster than productivity and this may affect the international cost competitiveness of the country's tradable sectors. In particular, theoretical models generally assume that the traded sector is leader in wage determination and there is mobility of labour across sectors which, in turn, ensures wage equalization. This is assumed, for example, by Froot and Rogoff [1995] and the so-called Scandinavian Model of wage determination (Aukrust [1970], see Section 3). If these models hold, during the process of catching-up excess inflation will be witnessed and the real exchange rate will appreciate, but, on the other hand, only wages in the non-traded sector should grow faster than productivity and therefore competitiveness should not be harmed. However, it can also happen that wage bargaining in the non-traded sector - which is not subject to international competition - and in the public sector which is influenced by political rather than productivity considerations - may lead to higher outcomes and, in turn, push traded sector wages up. Testing wage leadership in the case of transition countries is important because they are in the process of catching up: entry in the EU, which also fostered international labour mobility, is likely to have influenced wage determination in these countries, and it is possible that prices and wages converge to the western european level faster than productivity, thus leaving room for competitiveness losses. As long as the leader in wage setting is the traded sector, this problem might be less relevant. But if this is not the case, increased labor mobility together with union pressures might lead to a decoupling of real and nominal convergence, i.e. nominal convergence could occur faster than real convergence. From a policy perspective, this would be a worrisome result since we could expect catching-up to occur at the cost of large international imbalances.

The contribution of this paper is threefold: first, it outlines three alternative models of wage determination which we are likely to find in practice; second, while there is limited existing literature on public/private wage spillovers. No empirical work to date, to our knowledge, studies the issue from the three-sector perspective that is adopted here. Finally, this is the first work on the topic which focuses on transition countries.

The paper is organized as follows. Section 2 reviews the literature on wage spillovers across the public and private sector. Section 3 presents three alternative models of wage determination and causality. Section 4 outlines the empirical model, a Cointegrated VAR; section 5 describes the data set and section 6 presents the results of the empirical analysis. Section 7 concludes.

\section{Related literature on wage spillovers}

The literature on wage spillovers across sectors, in particular private and public wages, is quite scarce. Theoretical models generally assume that public wages are exogenous or follow the same pattern as private wages (Quadrini and Trigari [2007], Ardagna [2007]). Demekas and Kontolemis [2000], instead, in a static model show that public wages can affect private sector wages through the labor supply channel: when public wages increase, workers move to that sector, and private firms are forced to increase wages too. 
As far as the direction of causality is concerned, the main theoretical reference is the so-called Scandinavian model of wage determination (Aukrust [1970]). This model assumes that the sector that is open to international competition is the leader in wage setting since productivity should increase faster in the traded goods sector and firms there cannot increase wages above productivity in order to avoid losing competitiveness ${ }^{1}$. In this sense, also public sector wages should be led by private sector wages. Evidence in favor the Scandinavian Model was found by Aukrust for Norway, the U.S. and France, while Bemmels and Zaidi [1990] successfully applied it to Canada.

However, this model has been found to be at odds with more recent data. Ultimately, the results seem to be country-dependent. Demekas and Kontolemis [2000] find weak exogeneity of government wages over private wages. Jacobsson and Ohlsson [1994], in a Vector Error Correction Model for Sweden, find long-run wage leadership of the private sector, thus confirming the predictions of the Scandinavian model, but Friberg [2007], using a broader sectoral decomposition ${ }^{2}$ does not find evidence of the Scandinavian model for Sweden. Christou et al. [2007] show a bidirectional causality relationship between private and public sector wages in Romania using monthly wages over the period 1993-2006.

Lamo et al. [2008] used several empirical methods to study the co-movement and causality relationship between private and public wages using annual data for 18 OECD countries (plus the Euro Area as a whole), finding that private and public wages generally do not decouple and the former seem to exert a stronger influence on the latter than the reverse; moreover, they find that prices seem to play an important role in the transmission of wage leadership.

None of the cited works is applied to transition countries (with the exeption of Christou et al.), and, more importantly, none clearly decomposes the private sector into a traded and non-traded sector, which is relevant when we want to understand the role of wage spillovers in affecting competitiveness. In fact, as we will see in the next section, not only a leading role of public sector wages but also of non-traded goods sector wages can lead to traded sector wages growing faster than productivity and thus harm the country's international competitiveness.

\section{Three competing theories of wage determination}

When dealing with intersectoral wage spillovers, theoretical models generally assume that the leader in wage determination is the sector that is exposed to international competition, i.e. the traded sector. However, as it was outlined in the previous section, the results obtained by the empirical literature are often at odds with this hypothesis. Alternative models of intersectoral wage linkages can therefore be imagined.

In this section we will outline three alternative theories of wage determination and intersectoral wage spillovers. This will allow us to come up with testable hypotheses that will be taken to the data. The first model is the main theoretical reference as far as intersectoral wage linkages and expected causality is concerned, and it is the so-called "Scandinavian Model" of inflation, which was first developed by Aukrust [1970] $]^{3}$. The Scandinavian Model rests on three fundamental assumptions: (1) the different sectors in the economy can be classified as either traded (exposed) sectors or nontraded (sheltered) sectors; (2) wage increases in the traded sectors can be expected

\footnotetext{
${ }^{1}$ An outline of this model is presented in the next section.

${ }^{2}$ In particular, he distinguishes between private sector, manufacturing sector, construction, wholesale and retail trade, financial sector, central government and county/municipal government.

${ }^{3}$ Aukrust [1970] first developed this model to describe price dynamics in Norway, and tested it on that country. However, Aukrust's model was applied to other countries' data to test for intersectoral wage linkages: France, USA and Australia (Aukrust [1977]), Canada (Bemmels and Zaidi [1990]), Sweden (Frieberg et al. [2004], Frieberg [2007], Jacobson and Ohlsson [1994]).
} 
to be transmitted to wage increases in the non-traded sectors of the economy, and therefore wage decisions are not taken simultaneously; (3) the exchange rate is fixed. In the original model we have two sectors (traded, $T$, and nontraded, $N$ ) and two countries (home, $H$, and foreign, $F$ ). We add the public sector as a non-traded, non-market sector and label it $P$. The timing structure of the model is pictured in figure 1 , panel (a).

In this highly stylized model, nominal wages in the traded sector are determined by the productivity in that sector and the prices obtainable internationally for the output of those firms ${ }^{4}$ :

$$
w_{T, t}=p_{T, t}+c_{T, t}+\eta_{T \cdot 1, t}
$$

where $c_{T, t}$ is productivity and $\eta_{T}$ represents stationary deviations from this long-run equilibrium relation. Labor is mobile across sectors; for this reason wage equalization occurs:

$$
\begin{aligned}
& w_{N, t}=\alpha_{N .1}+\theta_{N .1} w_{T, t}+\eta_{N .1, t} \\
& w_{P, t}=\alpha_{P .1}+\theta_{P .1} w_{T, t}+\eta_{P .1, t}
\end{aligned}
$$

where $\theta_{i .1} \geq 0, i=N, P$ are parameters describing the degree of wage adaptability across sectors. The Scandinavian model concludes that not only should wages in different sectors co-move, but that transmission of wage shocks should be one to one, a testable hypothesis that we will term "full wage adaptability". In other words, according to the Scandinavian Model the deviations from equilibrium, $\eta_{j}, j=N, P, T$ should be stationary, $\alpha_{N .1}=\alpha_{P .1}=0$ and $\theta_{N .1}=\theta_{P .1}=1$.

Finally, the firms in the traded sector set the prices for their goods and services accordingly, in order to avoid losses ${ }^{5}$, so that

$$
p_{N, t}=w_{N, t}-c_{N, t}+\eta_{p n . t}
$$

As a result, non-traded goods prices will increase more than traded goods prices, a conclusion which is shared with the so-called "internal version" of the Balassa-Samuelson hypothesis.

An alternative argument may be relevant for transition countries that have entered the European Union. The catching up process of transition countries towards western european levels, in terms of productivity and price level, has been documented in many studies on the so-called BalassaSamuelson effect ${ }^{6}$. However, when a country joins the European Union, the liberalization of labor mobility across countries should itself foster wage convergence within the Union. This, in turn, can be due to convergence in productivity, but also to migration of labor to countries with higher wage levels or increased union pressures for wage raises. In the latter two cases, wage increases can harm the competitiveness of the country if they are above productivity growth.

As long as the traded sector is the leader in wage determination, pressures due to international competition will avoid wage increases in excess of productivity.

\footnotetext{
${ }^{4}$ The model outlined below heavily draws on Aukrust [1970].

${ }^{5}$ One additional assumption that we have left impliciti $s$ that productivity growth is higher in the traded sector than in the non-traded sector. This assumption, which is empirically sound, is also at the basis of the so-called Baumol-Bowen effect that the price wedge between non-tradables and tradables should be commoving with productivity. If this assumption did not hold, then we could either have $\mathrm{p}_{\mathrm{N}}$ growing more than $\mathrm{p}_{\mathrm{T}}$ (if firms in $\mathrm{N}$ set prices under mark-up pricing) or less than $\mathrm{p}_{\mathrm{T}}$ (if there is pricing-to-market in $\mathrm{N}$ ).

${ }^{6}$ A small subset includes Mihaljek and Klau [2001], Egert [2002², 2002b, 2002c, 2007], Fischer [2004], Dobrinsky [2006] and Staher [2010].
} 
Figure 1. Three competing models of wage spillovers

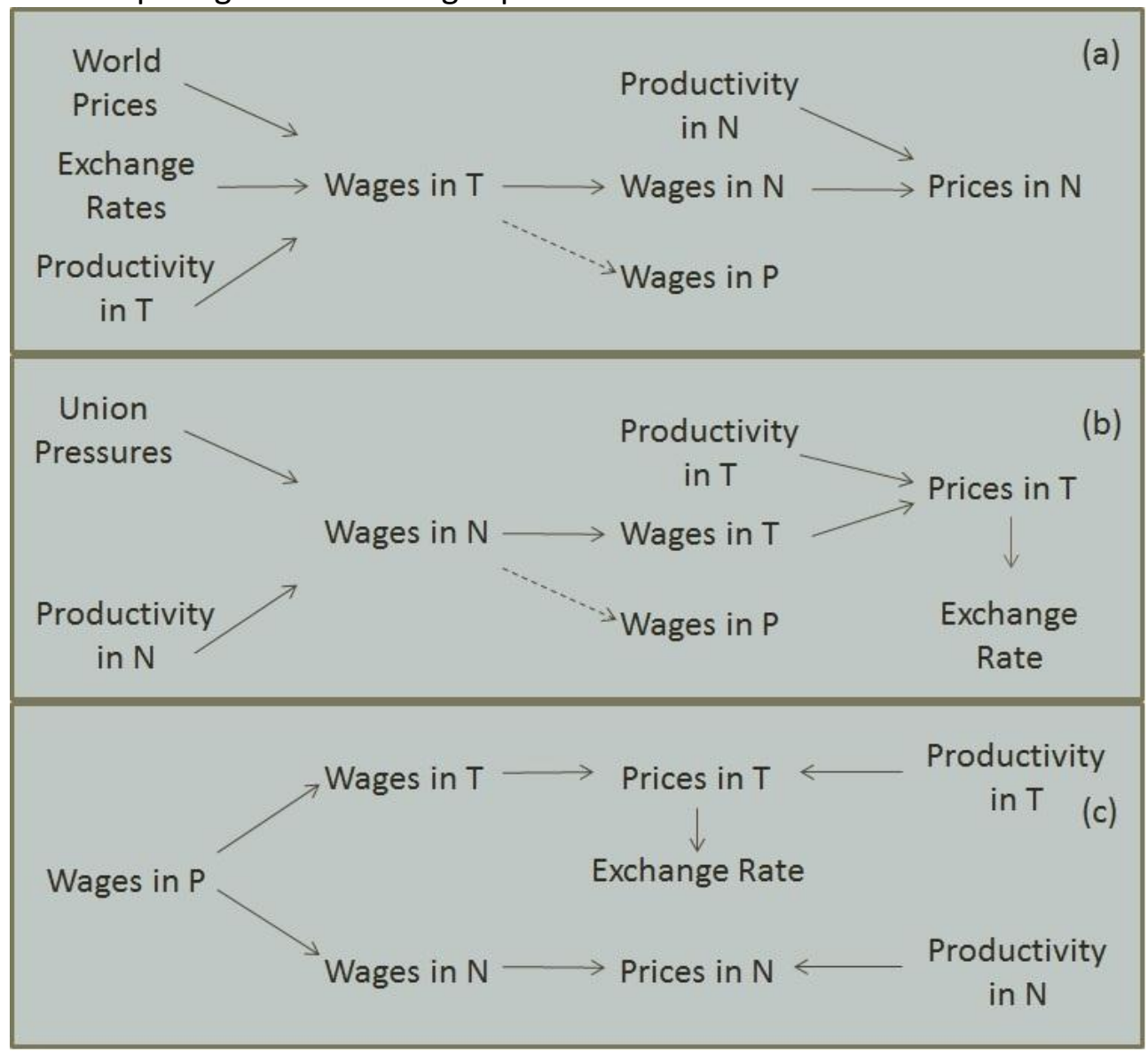

But alternative models of intersectoral wage spillovers could be present, and the empirical analysis in the next section will prove that this might indeed be the case.

As it was pointed out by Friberg [2007], non-traded sector firms operate in a less competitive environment, since they are not subject to international competition: therefore, wage bargaining in non-traded sectors may lead to higher outcomes, ceteris paribus. But this is not the only issue, since in the present paper we further divide non-traded sector wages between the market nontraded and non-market non-traded (public) sector. Theoretical models of public sector wage setting generally assume that wages for public employees are set exogenously or, as in Demekas and Kontolemis [2000], that the government maaximizes an objective function in public goods provision and public wages (a form of political patronage). In this sense, also wage bargaining in the public sector may lead to higher outcomes, depending on the political pressure that public employees are able to exert on the government. If the mobility of labor across sectors is high and therefore wages tend to equalize, a leading role in wage setting of either the public sector or the non-traded sector can harm international competitiveness.

We can sketch models of wage determination which are parallel to the Scandinavian model for these two cases.

A model with the non-traded sector leading is pictured in figure 1, panel (b). For practical reasons, we will call it the "wage mark-up model". Nominal wages in the non-traded sector are set according to productivity in that sector, the prices that firms can obtain on the internal market, and the mark-up on productivity that unions are able to extract from employers:

$$
w_{N, t}=p_{N, t}+c_{N, t}+\mu_{N, t}+\eta_{N, t}
$$


pressures for wage equalization across sectors due to free intersectoral labor mobility, as in the previous case, will make sure that wages in T and $\mathrm{P}$ adjust to $\mathrm{w}_{\mathrm{N}}$ :

$$
\begin{aligned}
& w_{T, t}=\alpha_{T .2}+\theta_{T .2} w_{N, t}+\eta_{T .2, t} \\
& w_{P, t}=\alpha_{P .2}+\theta_{P .2} w_{N, t}+\eta_{P .2, t}
\end{aligned}
$$

where again $\alpha_{T .2}=\alpha_{P .2}=0$ and $\theta_{T .2}=\theta_{P .2}=1$ if full wage adaptability holds and $\eta_{j}, j=N, P, T$ are stationary i.i.d. disturbances.

The firms in the traded sector, then, will set the prices of their goods according to the level of wages and the productivity in the sector:

$$
p_{T, t}=w_{T, t}-c_{T, t}+\eta_{p T . t^{7}}
$$

and this in turn causes real appreciation. Thus, unless a nominal exchange rate depreciation occurs, it will lead to the country's firms becoming less competitive on the international markets ${ }^{8}$. In this case, the presence of low wage adaptability $\left(\theta_{T .2}<1\right)$ might offset (at least partially) the negative effect of public sector wages on competitiveness.

Finally, Figure 1, panel (c) pictures the case of the public sector leading the other two. We will call this the "envy-effect model" (Friberg [2007], Strom [1995]).In this case, we assume following Ardagna [2007] and Quadrini and Trigari [2007] that the public sector wages are predetermined:

$$
w_{P, t}=\bar{w}
$$

where $\bar{w}>c_{i, t}, \mathrm{i}=\mathrm{N}, \mathrm{T}$, i.e. public wages lead wage determination and they grow faster than productivity in the other sectors. As in the previous cases, wage equalization then occurs:

$$
\begin{aligned}
& w_{T, t}=\alpha_{T .3}+\theta_{T .3} w_{P, t}+\eta_{T .3, t} \\
& w_{N, t}=\alpha_{N .3}+\theta_{N .3} w_{P, t}+\eta_{N .3, t}
\end{aligned}
$$

Again, full wage adaptability holds if $\theta_{\mathrm{i} .3}=1, \mathrm{i}=\mathrm{N}, \mathrm{T}$. As in the previous case, the consequences for the domestic firms' international competitiveness might be serious due to traded goods prices growing faster than productivity. Moreover, since wages in both market sectors ( $\mathrm{N}$ and $\mathrm{T}$ ) are growing ahead of productivity, in this latter case the result in terms of CPI inflation will be more serious than in the previous cases.

Albeit highly stylized, these models offer us an idea of the scenarios we are likely to find in an empirical analysis of wage spillovers and leve us with clear testable hypotheses to find out which model fits best in describing the wage setting process in a specific country.

\section{The Empirical Model}

\footnotetext{
${ }^{7}$ The implicit assumption here is that $c_{N, t}+\mu_{N, t}>c_{T, t}$.

${ }^{8}$ In order to avoid losing market share, firms in T might keep prices unchanged for some time, but this strategy would not be sustainable since $\mathrm{i}$ twill generate losses. Alternatively, they might reduce employment and/or try to push productivity up, for example by eliminating previous slack in the work process (see, for example, Juselius and Ordonez [2009]). However, to be able to account for this we would need a more general theoretical and empirical model which is beyond the scope of this paper.
} 
The ideal empirical model to test the assumptions embedded in the theoretical model sketched in the previous section, for reasons that will be clear shortly, is a Cointegrated VAR as developed by Johansen [1988, 1995]. The main advantage of the CVAR is that it is a completely data-driven approach, which puts reality ahead of theory, and can therefore challenge - as it has been proved in several recent works ${ }^{9}$ - theoretical macro models which have often been proved to fail to explain many empirical facts. Instead of pre-specifying the correct economic model from the outset, by using the CVAR we "let the data speak". At the same time, the CVAR does not have the drawback of Structural VARs which, in order to be identified, require a priori restrictions that are generally not testable. All restrictions imposed on the CVAR are testable, and this makes it a more robust tool for econometric analysis with respect to SVARs. One drawback of the CVAR is that it is quite data-demanding, which can be a problem when we deal with transition countries given the reduced data availability. However, in this specific case, given the dimension of the VAR (three variables) and the characteristics of the series (see next section) this problem is less relevant.

Suppose we have a vector of $p$ variables in time series. When the $p$ variables, in levels, are nonstationary and integrated of order $1, \mathrm{I}(1)$, their first difference will be $\mathrm{I}(0)$. Moreover, if two or more variables are I(1) but their linear combination is I(0), they are said to be cointegrated ( or $\mathrm{CI}(1,0))$. The CVAR, as we will see, has the variables in first differences as dependent variables but is simply a reparametrization of the VAR. Therefore, the value of the likelihood is the same and there is no information loss in moving from the VAR to the Cointegrated (or Vector Error Correction) counterpart.

A Cointegrated VAR model of order $n$ with $p$ variables, is defined as:

$$
\Delta x_{t}=\Pi \tilde{x}_{t-1}+\Gamma_{1} \Delta x_{t-1}+\cdots+\Gamma_{n} \Delta x_{t-n} \phi D_{t}+\mu+\varepsilon_{t} ; \varepsilon_{t} \sim \operatorname{Niid}(0, \Omega)
$$

where $D$ is a vector of dummy variables (seasonals and other unrestricted dummies), $m$ is a vector of constant terms ${ }^{10}$ and $W$ is the (pxp) covariance matrix of (white noise) residuals. $\lceil$, $, j=1, \ldots, n$ are the matrices of the short-run coefficients. When variables are I(1) and cointegrated, the matrix $P$ will be of rank $r<p$, where $r$ is the number of (long-run) cointegration relations. Therefore, the $P$ matrix can be decomposed as:

$$
\begin{aligned}
& \Pi=\alpha \tilde{\beta}^{\prime} ; \tilde{\beta}=\left[\begin{array}{llll}
\beta & 1 & \beta_{d} & \beta_{t}
\end{array}\right] ; \\
& {\widetilde{x^{\prime}}}_{t-1}^{\prime}=\left[\begin{array}{llll}
x_{t-1} & 1 & D_{s} & t
\end{array}\right]
\end{aligned}
$$

where 1 represents a constant restricted to lie in the cointegration relation, $D_{s}$ are dummies that do not cancel in the cointegration relations and $t$ is a linear trend. The $\mathrm{b}^{\prime} \mathrm{s}$ are called the cointegration relations while the a are the loadings. In other terms, the long run (stationary) relations that characterize the variables are the $\beta$ 's, while the $\alpha$ 's show how each variable adjusts to disequilibria in the corresponding long-run relation. The coefficients in the $a$ and $b$ matrices will not be, in general, identified (i.e. we have an infinite number of matrices $a$ and $b$ that, if multiplied, are equal to $P$ ); in order to achieve identification, we will need to impose restrictions on b. A Cointegrated VAR model is empirically identified when $r$-1 restrictions are imposed on each long-run relation. If the number of restrictions is larger, the model is overidentified and such restrictions are testable.

\footnotetext{
${ }^{9}$ See, for example, Juselius and Franchi [2007].

${ }^{10}$ Notice that an unrestricted constant in the differences is equivalent to a linear trend in the levels of the variables.
} 
Including a linear term (the time trend $t$ ) in the cointegration relations can be useful when variables in the system are trending and trends do not cancel in the cointegrating relations; the constant instead allows for a non-zero mean in the relation.

The CVAR, in sum, says that the changes in the variables in each period are given by adjustments to equilibrium relations and the effect of past changes in the variables of the system; all contemporaneous effects in the CVAR are in the covariance matrix; i.e. the CVAR is a reduced form model.

Moreover, the CVAR classifies the variables in $r$ long-run relations by which the system is pulled and $p$-r common stochastic trends, by which the system is pushed. In other words, when the rank is $r$, the shocks in the equations of the VAR can be rewritten as $r$ transitory shocks (i.e. shocks that cause disequilibria which are gradually absorbed through adjustment to the long-run relations) and $p-r$ permanent shocks. We can therefore re-write the CVAR in the so-called common trends representation:

$$
x_{t}=C \sum_{i=1}^{t}\left(\epsilon_{i}+\mu_{0}+\phi_{1} D p_{i}\right)+C^{\circ}(L)\left(v_{t}+\mu_{0}+\mu_{1} t\right)+\tilde{X}_{0}
$$

where Dp are permanent (shift) dummies and

$$
C=\beta_{\perp}\left(\alpha_{\perp} \Gamma \beta_{\perp}\right)^{-1} \alpha_{\perp}^{\prime}=\tilde{\beta}_{\perp} \alpha_{\perp}^{\prime}
$$

where $\alpha_{\perp}$ and $\beta_{\perp}$ are the $\mathrm{p} \times(\mathrm{p}-\mathrm{r})$ orthogonal complements of $\alpha$ and $\beta$ describing the common stochastic trends, $\alpha_{\perp} \sum \epsilon$, and their loadings.

If a variable is found to be weakly exogenous, i.e. it does not adjust to any cointegrating relation ${ }^{11}$, then the shocks to that variable are identified as one of the common stochastic trends of the system. In other words, the weakly exogenous variable "causes" movements in the other variables.

It should now be clear why the Cointegrated VAR model is a natural candidate to test empirically the predictions of the theoretical model sketched in the previous section. Theoretical models on wage determination make precise statements on the long-run relations as well as the causal links between wages in different sectors.

The "Scandinavian Model" and also the Froot and Rogoff [1995] model of the Balassa-Samuelson effect state that the open sector should be the driving force of the system, since on one hand productivity grows faster in this sector (as it has been empirically observed), and on the other hand it faces international competitiveness and therefore wages should increase in step with productivity to make sure that prices to not grow and there are no losses in competitiveness. Freedom of movement of labor across sectors, then, makes sure that wages are equalized.

The hypothesis of wage equalization (or, more precisely, constancy of the wage ratio) implies that in a model including wages in the three sectors (industry, services and public administration) we should be able to find two cointegrating (long-run) relations and one common trend ${ }^{12}$. The coefficients in the cointegration relation should satisfy long-run homogeneity, i.e. we should find one-to-one long-run relations and the constant in the cointegration vectors should be zero. Finally, in the Scandinavian Model, the common trend should be identified with shocks to industry wages, i.e. industry wages should be weakly exogenous.

\footnotetext{
${ }^{11}$ This amounts to testing that the corresponding row in the $\alpha$ matrix is zero.

${ }^{12}$ Moreover, the model should be specified with an unrestricted constant and and no trend, since the presence of a trend in the cointegrating relation would imply that one sector has been gaining purchasing power with respect to the others.
} 
Table 1. Testable hypothesis on wage spillovers

\begin{tabular}{|c|c|c|c|c|c|}
\hline Model & Leader & $\begin{array}{c}\text { Wage } \\
\text { adaptability } \\
\text { hypothesis }\end{array}$ & $\begin{array}{c}\text { Cointegration } \\
\text { Rank }\end{array}$ & $\begin{array}{c}\text { Wage } \\
\text { equalization } \\
\text { hypothesis }\end{array}$ & $\begin{array}{c}\text { Granger non- } \\
\text { Causality }\end{array}$ \\
\hline 1. Scandinavian Model & $\mathbf{W}_{\mathrm{T}}$ & $\theta_{N}=\theta_{P}=1$ & 2 & $\alpha_{N .1}=\alpha_{N .1}=0$ & $\begin{array}{l}w_{P} \stackrel{n o t}{\longrightarrow} w_{T} \\
w_{N} \stackrel{n o t}{\longrightarrow} w_{T}\end{array}$ \\
\hline 2. Wage mark-up model & $w_{N}$ & $\theta_{\mathrm{T}}=\theta_{\mathrm{P}}=1$ & & $\alpha_{T .2}=\alpha_{P .2}=0$ & $\begin{array}{l}\stackrel{n o t}{\rightarrow} w_{N} \\
w_{T} \stackrel{n o t}{\longrightarrow} w_{N}\end{array}$ \\
\hline 3. Envy-effect model & $W_{P}$ & $\theta_{\mathrm{N}}=\theta_{\mathrm{T}}=1$ & & $\alpha_{N .3}=\alpha_{T .3}=0$ & $\begin{array}{l}w_{T} \stackrel{n o t}{\longrightarrow} w_{P} \\
w_{N} \stackrel{n o t}{\longrightarrow} w_{P}\end{array}$ \\
\hline
\end{tabular}

On the other hand, if the hypothesis of one-to-one relations (coefficients in the $\beta$-vector equal to 1 ) is rejected, this is interpreted as a low wage adaptability between the sectors considered (see Friberg [2007]). If less than two cointegration relations are found, this means that there is more than one common trend affecting the wages: in other words, a weaker form of our three theoretical models holds. For example, if both Services and Industry are found to be weakly exogenous, with public sector wages adjusting, this would imply that the (market) traded and nontraded sector wages are subject to different kinds of shocks, and also a lower mobility of labour across sectors is present: otherwise wage equalization would hold. By classifying the model into pulling and pushing forces, we will be able to identify how the wage shocks load into the three different sectors. If the weak exogeneity of traded sector wages does not hold, the empirical model suggests that the Scandinavian model is not a good approximation of wage dynamics in the country under analysis.

In other terms, absence of weak exogeneity of $\mathrm{W}_{T}$ would imply that the traded sector has not been a driving force in wage determination, and rather it has been influenced by shocks to the other sectors, leaving room for competitiveness loss if wages have grown more than productivity.

Table 1 summarizes the hypotheses embedded in the theoretical models outlined in Section 3 within the Cointegrated VAR framework.

\section{The Data and empirical results}

Our dataset contains quarterly data from 2000Q1 until 201002 for ten Central and Eastern European Countries that have joined the European Union in one of the two waves of 2004 and 2007 (Bulgaria, Czech Republic, Estonia, Hungary, Latvia, Lithuania, Poland, Romania, Slovak Republic, Slovenia). The time sample was chosen in order to make sure to have data for all countries, as well as excluding data from the very first years after independence which might be less reliable or, for what concerns the consumer price index, depend heavily on price administration.

There are three wage series for each country, Industry (proxying the traded sector), Services (proxying the market non-traded sector) and Public Administration (the non-market, non-traded sector) ${ }^{13}$. While the definition of the Public Sector (wages in public administration, defence and compulsory social security) is not really debatable, some hypotheses had necessarily to be done in order to define the traded and non-traded sector. To this end, we have followed a common practice in the literature on the Balassa-Samuelson effect to identify the traded sector with industry (excluding construction, which is not unanimously treated in the literature) and the

\footnotetext{
${ }^{13}$ The exact definition of the series and the sources is given in Appendix 1.
} 
market nontraded sector with Services of the business economy ${ }^{14}$. Agriculture is excluded from the sample as agricultural prices heavily rely on state support and price administration, and are influenced by policies as the CAP in the EU.

Finally, the wage indexes are deflated using the Harmonized CPI index. This is done in order to concentrate on the relationship between real wages, excluding price shocks from the model.

Most of the empirical works on this issue define wages as compensation per employee in the corresponding sector, calculated as compensation of employees divided by the number of workers in that sector; however, these data are only available on an annual basis and the available time series for transition countries are too short to use annual data ${ }^{15}$. The dimension of the VARs estimated in this paper makes the use of quarterly data suitable; moreover, unlike other long-run equilibrium relations, deviations from a long-run equilibrium of wage series are generally less persistent, and therefore 11 years represent a long enough time span to detect cointegration. Finally, we prefer using quarterly data to annual data because the latter can be misleading - or not informative - if sectoral wage spillovers occur within the year, i.e. with a frequency which is higher than that of the sample. As we will show, our estimates of the $\alpha$ coefficients indeed suggest that disequilibria in the wage relations are in all cases absorbed within the year.

As already stated, the empirical model is a Vector Error Correction Model in three variables: (real) wages in Industry, $w_{1}$, Services, $w_{s}$, and Public Administration, $w_{p}$. In the majority of cases the model is a Cointegrated VAR with an unrestricted constant and no trend, but exceptions are present ${ }^{16}$. Table 2 shows the results of the cointegration rank test. We do not limit ourselves to looking at the results of the trace test but, as it is common in the literature, combine it with information on the largest unrestricted root of the characteristic polynomial ${ }_{17}$. When they are conflicting, we look at the significance of the adjustment coefficients in the corresponding row of the $\alpha$-matrix to see if they are significant, in order to make sure that, by excluding a cointegration relation, we are not wasting potentially important information.

Only for three countries out of ten (Estonia, Poland and Slovakia) we could not reject the null of a rank of 2 . In the other cases, the rank is 1 . This might suggest a low intersectoral mobility across sectors, so that the three wage series do not share a single common trend but two different trends.

We can now move to testing restrictions on the cointegration vectors, the 8 matrices, in order to find out the degree of wage adaptability; on the other hand, by testing restrictions on the $\alpha$ matrices (i.e. testing for weak exogeneity) we will be able to classify the variables in the system in pushing and pulling forces, i.e. variables that drove the system out of equilibrium and variables which brought the system back to equilibrium, adjusting to the cointegration relations.

Tables 3-5 report the results of the empirical model. Table 3 provides the null hypothesis, the imposed restrictions and normalization on the 6 -vectors and the likelihood test results. If we have two cointegration relations and a null hypothesis of one or several one-to-one relations can be rejected at the $10 \%$ level, we interpret this as low wage adaptability (see Friberg [2007]).

\footnotetext{
14 The literature generally identifies the open sector with industry and the sheltered sector with services or "all the rest". For example, Egert [2001, 2002a, 2002b, 2002c] and Golinelli and Orsi [2001] define Industry as the Open sector and the rest as the closed sector. Halpern and Wyplosz [2001] include respectively Industry and Services, and exclude construction from the latter. Agriculture is excluded in Coricelli and Jazbec [2001], De Broeck and Slot [2001], and Rother [2000]. Nenovsky and Dimitrova [2002] include also construction in the open sector.

${ }^{15}$ For example, Lamo et al. [2008] and Demekas and Kontolemis [2000]. Friberg [2007], instead, uses average monthly wages in the corresponding sector.

${ }^{16}$ The exact specification of the deterministic part and the order of the underlying VAR, country by country, is given in Appendix 2.
} 
Table 2. Cointegration rank test results.

\begin{tabular}{|c|c|c|c|c|}
\hline Country & Null & Trace test $p$-value & Largest unrestricted characteristic root & Choice \\
\hline \multirow[t]{3}{*}{ Bulgaria } & $r=0$ & 0.028 & 0.294 & \multirow{3}{*}{$r=1$} \\
\hline & $r \leq 1$ & 0.418 & 0.648 & \\
\hline & $r \leq 2$ & 0.897 & 0.910 & \\
\hline \multirow[t]{3}{*}{ Czech Republic } & $r=0$ & 0.018 & 0.349 & \multirow{3}{*}{$r=1$} \\
\hline & $r \leq 1$ & 0.071 & 0.384 & \\
\hline & $r \leq 2$ & 0.295 & 0.927 & \\
\hline \multirow[t]{3}{*}{ Estonia } & $r=0$ & 0.000 & 0.901 & \multirow{3}{*}{$r=2$} \\
\hline & $r \leq 1$ & 0.005 & 0.846 & \\
\hline & $r \leq 2$ & 0.126 & 0.846 & \\
\hline \multirow[t]{3}{*}{ Hungary } & $r=0$ & 0.030 & 0.593 & \multirow{3}{*}{$r=1$} \\
\hline & $r \leq 1$ & 0.188 & 0.434 & \\
\hline & $r \leq 2$ & 0.380 & 0.771 & \\
\hline \multirow[t]{3}{*}{ Latvia } & $r=0$ & 0.026 & 0.415 & \multirow{3}{*}{$r=1$} \\
\hline & $r \leq 1$ & 0.785 & 0.300 & \\
\hline & $r \leq 2$ & 0.678 & 1.000 & \\
\hline \multirow[t]{3}{*}{ Lithuania } & $r=0$ & 0.298 & 0.614 & \multirow{3}{*}{$r=1$} \\
\hline & $r \leq 1$ & 0.459 & 0.690 & \\
\hline & $r \leq 2$ & 0.064 & 0.877 & \\
\hline \multirow[t]{3}{*}{ Poland } & $r=0$ & 0.003 & 0.529 & \multirow{3}{*}{$r=2$} \\
\hline & $r \leq 1$ & 0.074 & 0.675 & \\
\hline & $r \leq 2$ & 0.183 & 0.659 & \\
\hline \multirow[t]{3}{*}{ Romania } & $r=0$ & 0.013 & 0.364 & \multirow{3}{*}{$r=1$} \\
\hline & $r \leq 1$ & 0.195 & 0.330 & \\
\hline & $r \leq 2$ & 0.567 & 0.722 & \\
\hline \multirow[t]{3}{*}{ Slovak Republic } & $r=0$ & 0.001 & N.A. & \multirow{3}{*}{$r=2$} \\
\hline & $r \leq 1$ & 0.019 & 0.237 & \\
\hline & $r \leq 2$ & 0.162 & 0.333 & \\
\hline \multirow[t]{3}{*}{ Slovenia } & $r=0$ & 0.658 & 0.697 & \multirow{3}{*}{$r=1$} \\
\hline & $r \leq 1$ & 0.682 & 0.706 & \\
\hline & $r \leq 2$ & 0.957 & 0.723 & \\
\hline
\end{tabular}

Note: the rank choice suggested by each method is indicated in boldface.

For economic identification and making the vectors meaningful, the vectors were normalized to the variable which is adjusting to the corresponding cointegration relation. Table 4 reports the results on weak exogeneity (i.e. the "pushing forces" of the system) and table 5 shows the common trends representation of the model, where the coefficients to the stochastic trends of the system are reported.

Bulgaria shows only one cointegration relation and Services are weakly exogenous, while the weak exogeneity of Industry and Public Sector is rejected; the joint hypothesis of Industry and Services being weakly exogenous is rejected at $5 \%$ but not at $1 \%$. No restriction on the $b$ vector was accepted. Looking at the common trends representation, we see that shocks to industry wages had a significant permanent effect only on the industry sector, while shocks to the services sector significantly affected the services and public sector. In other words, we can label the two wage shocks as a traded goods wage shock and a non-traded sector shock.

The Czech Republic exhibits one cointegration vector; interestingly, the two closed sector wages, $w_{N}$ and $w_{p}$, are found to be weakly exogenous and the joint weak exogeneity could not be rejected with a $p$-value of 0.113 . The traded sector wages, therefore, have been adjusting, and table 4 shows that the sector that has been leading on industry wages was the public sector. 
Table 3. Test results for sectoral wage adaptability.

\begin{tabular}{|c|c|c|c|c|}
\hline Country & $\#$ of Coint. Vectors & Restriction/Normalization & LR-Statistic & $\mathrm{p}$-value \\
\hline Bulgaria & 1 & $\hat{\beta}^{\prime}=\left[\begin{array}{lll}\beta_{1 I} & \beta_{1 S} & 1\end{array}\right]^{\prime}$ & N.A. & N.A. \\
\hline Czech Republic & 1 & $\hat{\beta}^{\prime}=\left[\begin{array}{lll}1 & \beta_{1 S} & \beta_{1 P}\end{array}\right]^{\prime}$ & N.A. & N.A. \\
\hline Estonia & 2 & $\begin{aligned} \hat{\beta}^{\prime} & =\left[\begin{array}{ccc}1 & -1 & 0 \\
0 & 1 & -1\end{array}\right]^{\prime} \\
\hat{\beta}^{\prime} & =\left[\begin{array}{ccc}\beta_{1 I} & -1 & 0 \\
0 & \beta_{2 S} & -1\end{array}\right]^{\prime}\end{aligned}$ & 19.259 & {$[0.000]$} \\
\hline Hungary & 1 & $\hat{\beta}^{\prime}=\left[\begin{array}{lll}\beta_{1 I} & 1 & 1-\beta_{1 I}\end{array}\right]^{\prime}$ & 3.691 & [0.449] \\
\hline Latvia & 1 & $\hat{\beta}^{\prime}=\left[\begin{array}{lll}1 & \beta_{1 S} & 0\end{array}\right]^{\prime}$ & 0.749 & [0.387] \\
\hline Lithuania & 1 & $\hat{\beta}^{\prime}=\left[\begin{array}{lll}\beta_{1 I} & \beta_{1 S} & 1\end{array}\right]$ & N.A. & N.A. \\
\hline Poland & 2 & $\begin{aligned} \hat{\beta}^{\prime} & =\left[\begin{array}{ccc}1 & -1 & 0 \\
0 & 1 & -1\end{array}\right]^{\prime} \\
\hat{\beta}^{\prime} & =\left[\begin{array}{ccc}\beta_{1 I} & -1 & 0 \\
0 & \beta_{2 S} & -1\end{array}\right]^{\prime}\end{aligned}$ & 15.027 & {$[0.102]^{17}$} \\
\hline Romania & 1 & $\hat{\beta}^{\prime}=\left[\begin{array}{lll}1 & \beta_{1 S} & \beta_{1 P}\end{array}\right]^{\prime}$ & N.A. & N.A. \\
\hline Slovak Republic & 2 & $\hat{\beta}^{\prime}=\left[\begin{array}{ccc}-1 & 1 & 0 \\
0 & -1 & 1\end{array}\right]^{\prime}$ & 7.589 & [0.108] \\
\hline Slovenia & 1 & $\hat{\beta}^{\prime}=\left[\begin{array}{lll}\beta_{1 I} & 1-\beta_{1 I} & 1\end{array}\right]^{\prime}$ & 1.879 & [0.598] \\
\hline
\end{tabular}

This structure of wage spillovers shows a potential for wage costs increasing more than productivity and competitiveness loss in the Czech Republic.

Estonia shows two cointegration relations; however, there is not full wage adaptability since the hypothesis of long-run homogeneity is rejected at all significance levels. On the other hand, industry wages are weakly exogenous and shocks to this sectors load significantly on the other sectors, making the "Scandinavian Model" a good approximation of the functioning of the labor market in this country.

In the case of Hungary only one cointegration vector was found; industry and the public sector wages are weakly exogenous and the services sector wages adjust to a cointegration vector that is a linear combination of the other two. More interestingly, shocks public sector wages appear not to have influenced the other sectors' wages in the long run, while the Services sectors were led by Industry wages shocks.

Latvia has one cointegration relation with the Industry sector being the pulling force, while the public and services sector are pushing. Moreover, public sector wages are long-run excludable (i.e. the coefficient in the cointegration vector was restricted to zero) but shocks to the public sector wages are the only ones that significantly affected the three variables in the system in the long run.

In other words, developments in wages in the public sector led those in other sectors.

Lithuania presents one cointegration relation; Industry and Services wages are weakly exogenous and public sector wages are adjusting. Moreover, from the common trends representation we can see that shocks to the industry sector only have a significant long-term effect on that sector, while shocks to the services sector significantly affect public sector wages in the long run.

Poland shows two cointegration relations but the null of full wage adaptability was rejected at all significance levels, even when it was tested separately for each cointegration vector.

\footnotetext{
${ }^{17}$ There are 5 restrictions in this model, and a test on restrictions is therefore available, since we also restricted the linear trend to zero in both cointegrating vectors and the trend break to zero in the first vector.
} 
Table 4. Test results for weak exogeneity.

\begin{tabular}{|c|c|c|c|c|}
\hline Country & Industry & Services & Public & Joint weak exogeneity test \\
\hline Bulgaria & $\begin{array}{c}4.613 \\
{[0.032]}\end{array}$ & $\begin{array}{c}0.333 \\
{[0.564]}\end{array}$ & $\begin{array}{c}9.977 \\
{[0.002]}\end{array}$ & Industry and Services: 6.826 [0.043] \\
\hline Czech Republic & $\begin{array}{c}4.025 \\
{[0.045]} \\
\end{array}$ & $\begin{array}{c}2.371 \\
{[0.124]}\end{array}$ & $\begin{array}{c}0.449 \\
{[0.503]}\end{array}$ & Services and Public: 4.361 [0.113] \\
\hline Estonia & $\begin{array}{c}6.072 \\
{[0.048]}\end{array}$ & $\begin{array}{c}8.894 \\
{[0.012]}\end{array}$ & $\begin{array}{l}16.998 \\
{[0.000]}\end{array}$ & \\
\hline Hungary & $\begin{array}{c}0.029 \\
{[0.865]}\end{array}$ & $\begin{array}{c}6.094 \\
{[0.014]}\end{array}$ & $\begin{array}{c}0.692 \\
{[0.405]}\end{array}$ & Industry and Public: 0.711 [0.701] \\
\hline Latvia & $\begin{array}{c}2.344 \\
{[0.126]}\end{array}$ & $\begin{array}{c}0.997 \\
{[0.318]}\end{array}$ & $\begin{array}{c}0.002 \\
{[0.962]}\end{array}$ & $\begin{array}{l}\text { Industry and Services: } 29.101 \text { [0.000] } \\
\text { Industry and Public: } 4.868 \text { [0.088] } \\
\text { Services and Public: } 1.745 \text { [0.418] }\end{array}$ \\
\hline Lithuania & $\begin{array}{c}1.007 \\
{[0.316]}\end{array}$ & $\begin{array}{c}0.001 \\
{[0.979]}\end{array}$ & $\begin{array}{c}5.693 \\
{[0.017]}\end{array}$ & Industry and Services: 2.159 [0.340] \\
\hline Poland & $\begin{array}{c}4.698 \\
{[0.095]}\end{array}$ & $\begin{array}{c}2.316 \\
{[0.314]}\end{array}$ & $\begin{array}{l}13.487 \\
{[0.001]}\end{array}$ & \\
\hline Romania & $\begin{array}{l}12.997 \\
{[0.000]}\end{array}$ & $\begin{array}{c}4.396 \\
{[0.036]}\end{array}$ & $\begin{array}{c}0.718 \\
{[0.397]} \\
\end{array}$ & Services and Public: 4.778 [0.092] \\
\hline $\begin{array}{l}\text { Slovak } \\
\text { Republic }\end{array}$ & $\begin{array}{c}2.670 \\
{[0.263]}\end{array}$ & $\begin{array}{c}6.567 \\
{[0.037]}\end{array}$ & $\begin{array}{l}12.458 \\
{[0.002]}\end{array}$ & \\
\hline Slovenia & $\begin{array}{c}1.317 \\
{[0.251]}\end{array}$ & $\begin{array}{c}0.030 \\
{[0.862]}\end{array}$ & $\begin{array}{c}3.988 \\
{[0.046]}\end{array}$ & Industry and Services: 1.857 [0.395] \\
\hline
\end{tabular}

LR tests, distributed as $\chi_{r}^{2}$, where $r=$ number of cointegrating relations. P-values in brackets.

In this case, the services sector wages are found to be weakly exogenous, with shocks to this sector pushing the system.

Romania presents only one cointegration relation with the Services and Public sector being weakly exogenous, the joint hypothesis not rejected with a p-value of 0.092 . Moreover, as in the case of the Czech Republic, shocks to public wages load significantly on industry wages, while the services sector does not significantly impact on the other sectors in the long run.

Interestingly, the Slovak Republic is the only country for which all hypotheses in the Scandinavian model and Balassa-Samuelson model (as concerns wage determination) are fulfilled. There are two cointegration vectors, full wage adaptability and Industry is weakly exogenous and significantly loading onto the other sectors.

Finally, Slovenia has one cointegration relation, where the public sector wages adjust to a weighted average of Industry and the Services, and the latter two sectors being jointly weakly exogenous and shocks to these variables significantly affecting public sector wages.

\section{Conclusions}

This paper analysed spillovers in wage determination across sectors in ten european transition countries that joined the European Union within the last decade. Several previous studies have shown, either with a descriptive approach or using econometric techniques, that wages in different sectors generally equalize or, more generally, the wage ratio tends to be constant. However, as it was discussed in Section 3 using a stylized theoretical model, different frameworks leads and lags in wage determination may have different impacts as regards the international cost competitiveness of a country's firms. 
Table 5. Common Trends representation: estimated elements of the $C$ matrix

\begin{tabular}{|c|c|c|c|c|c|}
\hline \multirow{2}{*}{ Country } & \multirow{2}{*}{ Equation } & \multicolumn{4}{|c|}{ Shocks } \\
\hline & & $\varepsilon_{\mid}$ & $\varepsilon_{\mathrm{S}}$ & $\varepsilon_{\mathrm{p}}$ & Det. Trend \\
\hline \multirow{3}{*}{ Bulgaria } & $w_{l t}$ & $1.146[2.708]$ & $0.375[0.687]$ & 0.000 [N.A.] & 0.009 \\
\hline & $w_{S t}$ & $0.077[0.179]$ & $1.363[2.463]$ & 0.000 [N.A.] & 0.013 \\
\hline & $W_{P t}$ & $-0.365[-0.804]$ & $1.771[3.023]$ & 0.000 [N.A.] & 0.015 \\
\hline \multirow{3}{*}{ Czech Republic } & $w_{l t}$ & 0.000 [N.A.] & 0.212 [1.540] & $0.518[2.018]$ & 0.012 \\
\hline & $w_{S t}$ & 0.000 [N.A.] & $0.849[3.995]$ & $0.286[0.721]$ & 0.011 \\
\hline & $W_{P t}$ & 0.000 [N.A.] & $0.031[0.108]$ & $1.398[2.576]$ & 0.011 \\
\hline \multirow{3}{*}{ Estonia } & $w_{l t}$ & & & & \\
\hline & $w_{S t}$ & & & & \\
\hline & $w_{P t}$ & & & & \\
\hline \multirow{3}{*}{ Hungary } & $w_{l t}$ & $1.166[3.111]$ & 0.000 [N.A.] & $-0.010[-0.167]$ & 0.008 \\
\hline & $w_{S t}$ & $1.207[2.690]$ & 0.000 [N.A.] & $0.109[1.461]$ & 0.008 \\
\hline & $W_{P t}$ & $1.448[1.106]$ & 0.000 [N.A.] & 0.812 [3.742] & 0.009 \\
\hline \multirow{3}{*}{ Latvia } & $w_{l t}$ & $0.000[$ N.A.] & $0.378[0.920]$ & $0.412[2.408]$ & 0.012 \\
\hline & $w_{S t}$ & 0.000 [N.A.] & $0.445[0.920]$ & $0.484[2.408]$ & 0.014 \\
\hline & $W_{P t}$ & 0.000 [N.A.] & $-1.202[-0.980]$ & $1.961[3.840]$ & 0.005 \\
\hline \multirow{3}{*}{ Lithuania } & $w_{I t}$ & $2.547[2.152]$ & $0.064[0.067]$ & 0.000 [N.A.] & 0.009 \\
\hline & $w_{s t}$ & $1.660[1.414]$ & $0.953[1.012]$ & 0.000 [N.A.] & 0.009 \\
\hline & $W_{P t}$ & $0.127[0.132]$ & $1.728[2.251]$ & 0.000 [N.A.] & 0.006 \\
\hline \multirow{3}{*}{ Poland } & $w_{l t}$ & $0.000[$ N.A. $]$ & $0.653[4.221]$ & 0.000 [N.A.] & 0.010 \\
\hline & $w_{S t}$ & $0.000[$ N.A. $]$ & $0.618[4.221]$ & $0.000[$ N.A. $]$ & 0.009 \\
\hline & $W_{P t}$ & 0.000 [N.A.] & $0.597[4.221]$ & 0.000 [N.A.] & 0.009 \\
\hline \multirow{3}{*}{ Romania } & $w_{I t}$ & 0.000 [N.A.] & $-0.050[-0.347]$ & $0.333[3.284]$ & 0.020 \\
\hline & $w_{S t}$ & 0.000 [N.A.] & $0.931[4.972]$ & $0.010[0.076]$ & 0.018 \\
\hline & $W_{P t}$ & 0.000 [N.A.] & $0.319[0.932]$ & $0.703[2.914]$ & 0.031 \\
\hline \multirow{3}{*}{ Slovak Republic } & $w_{l t}$ & $0.815[3.277]$ & $0.000[$ N.A.] & 0.000 [N.A.] & 0.008 \\
\hline & $w_{S t}$ & $0.774[3.277]$ & 0.000 [N.A.] & 0.000 [N.A.] & 0.008 \\
\hline & $W_{P t}$ & $0.945[3.277]$ & 0.000 [N.A. $]$ & 0.000 [N.A.] & 0.009 \\
\hline \multirow{3}{*}{ Slovenia } & $w_{l t}$ & $0.442[2.383]$ & $0.283[0.802]$ & 0.000 [N.A.] & 0.008 \\
\hline & $w_{S t}$ & $-0.193[-1.052]$ & $0.932[2.669]$ & 0.000 [N.A.] & 0.006 \\
\hline & $W_{P t}$ & $-0.653[-3.088]$ & $1.364[3.386]$ & 0.000 [N.A.] & 0.003 \\
\hline
\end{tabular}

T-values in parenthesis. Significant long-run effects of the shocks on the dependent variable are given in boldface.

Table 6. Models of wage spillovers

\begin{tabular}{lllllllllll}
\hline & Bulgaria & $\begin{array}{l}\text { Czech } \\
\text { Rep. }\end{array}$ & Estonia & Hungary & Latvia & Lithuania & Poland & Romania & $\begin{array}{l}\text { Slovak } \\
\text { Rep. }\end{array}$ & Slovenia \\
\hline Model & 1 & 3 & 1 & 1 & 3 & 1 & 2 & 3 & 1 & 1 \\
\hline
\end{tabular}

Note: 1. Scandinavian Model; 2. Wage mark-up model; 3. Envy-effect model.

When wages in sectors that are not exposed to international competition lead the process of wage setting, inter-sectoral labor mobility as well as union pressure will cause the traded sector wages to grow more than productivity, thus harming competitiveness.

In this case, the catching up process will be characterized by wages converging faster than productivity, i.e. nominal convergence and real convergence will decouple. The main results of the paper are the following: first of all, in transition countries we do not have full wage adaptability, and in most cases two common trends are present, meaning that wage setting in the "weakly 
exogenous" sectors has been, in some sense, autonomous. This means that inter-sectoral labour mobility was low. Second, the "right" model to describe wage interactions is different across countries. In Section 3, we have outlined three alternative models of wage spillovers and derived the hypotheses they implied. Table 6 shows the model that best describes wage setting in each of the sample countries, although, given the result on the number of cointegration relations, a somehow weaker version of those models holds, since labor mobility was found to be low.

Only for the case of Slovak Republic the Scandinavian model, which is the dominant model of wage spillovers in the literature, was found to hold in its strict version. Romania, the Czech Republic and Latvia are in the opposite situation, with public sector wages which were found to be weakly exogenous (strongly exogenous in the case of Latvia) and Granger-causing traded and nontraded sector wages.

In the case of Poland, nontraded sector wages have been leading wage determination. For these countries, wages and prices have thus been converging at a higher speed with respect to productivity, suggesting that international competitiveness might be damaged by the current system.

As far as the remaining countries are concerned, while traded sector wages have been weakly exogenous, low inter-sectoral labour mobility made sure that wage setting in the non-traded or public sector was not long-run affected by the open sector.

\section{References}

Ardagna, S. (2007) "Fiscal Policy in unionized labor markets" Journal of Economic Dynamics and Control 31, 1498-1534.

Aukrust, O. (1977) "Inflation in the open economy: a Norwegian Model", Artikler no.96, Statistisk Sentralbyra, Oslo.

Balassa, B. (1964) "The Purchasing-Power Parity Doctrine: a Reappraisal" Journl of Political Economy 72(6), December, pp. 584-96.

Demekas, D.G. and Z.G. Kontolemis (2000) "Government employment and wages and labour market performance" Oxford Bulletin of Economics and Statistics 62(3), 391-415.

Egert, B. (2002) "Investigating the Balassa-Samuelson hypothesis in the transition" Economics of Transition Vol. 10 (2), pp. 273-309.

Egert, B. (2003) "Nominal and Real Convergence in Estonia: The Balassa-Samuelson (dis)connection" William Davidson Institute Working Paper Series 556, William Davidson Institute at the University of Michigan Stephen M. Ross Business School.

Egert, B. and I. Drine, K. Lommatzsch, C. Rault, (2003) "The Balassa-Samuelson effect in Central and Eastern Europe: myth or reality?" Journal of Comparative Economics vol. 31 (3), pp. 552-72.

Egert, B. (2007) "Real convergence, Price level convergence and Inflation in Europe" Bruegel Working Paper $N^{\circ} 2007 / 2$.

Fischer, C. (2004) "Real Currency Appreciation in Accession Countries: Balassa-Samuelson and Investment Demand" Review of World Economics 2004, 140 (2) pp.179-210. 
Friberg, K. (2007) "Intersectoral Wage Linkages: the case of Sweden" Empirical Economics 32: 161184.

Froot, K. and K. Rogoff (1995) "Perspectives on PPP and Long-Run Real Exchange Rates" in G. Grossman and K.Rogoff (eds.), Handbook of International Economics 3. Amsterdam: Elsevier.

Jacobson, T. and H. Ohlsson (1994) "Long-run relations between private and public sector wages in Sweden" Empirical Economics 19, 343-360.

Johansen, S. (1995) Likelihood-based inference in Cointegrated Vector Autoregressive Models, Oxford University Press.

Juselius, K. (2006) The Cointegrated VAR Model: Methodology and Application, Oxford University Press.

Juselius, K. and J. Ordonez (2009) "Balassa-Samuelson and Wage, Price and Unemployment Dynamics in the Spanish Transition to EMU Membership" Economics e-journal 3, 2009-4.

Lamo, A., Perez, J.J. And L. Schuknecht (2008) "Public and Private sector wages. Co-Movement and Causality" ECB Working Paper No. 963.

Mihaljek, D. and M. Klau (2003) "The Balassa-Samuelson effect in central Europe: a disaggregated analysis" BIS Working Paper No. 143.

Quadrini, V. and A. Trigari (2007) "Public Employment and the Business Cycle" Scandinavian Journal of Economics 109 (4), 723-742.

Samuelson P.A. (1964) "Theoretical Notes on Trade Problems" The Review of Economics and Statistics vol. 46, No. 2, 145-154.

Strom, B. (1995) "Envy, Fairness and Political Influence in local government wage determination: evidence from Norway", Economica 62, N. 247, 389-409.

Tagtstrom, S. (2000) "The wage spread between different sectors in Sweden" Sveriges Riksbank Economic Review 4/2000. 


\section{Appendix 1. Data Sources}

\begin{tabular}{|l|l|}
\hline Variable & Source and Definition \\
\hline Industry Wages & $\begin{array}{l}\text { Eurostat, LCI (Labor Cost Index) - Wages and Salaries. Seasonally adjusted } \\
\text { and adjusted data by working days - B-E (“Industry except construction”). } \\
\text { Nominal value. }\end{array}$ \\
\hline Services Wages & $\begin{array}{l}\text { Eurostat, LCl (Labor Cost Index) - Wages and Salaries. Seasonally adjusted } \\
\text { and adjusted data by working days - G-N (“Services of the business } \\
\text { economy"). Nominal value. }\end{array}$ \\
\hline Public Wages & $\begin{array}{l}\text { Eurostat, LCl (Labor Cost Index) - Wages and Salaries. Seasonally adjusted } \\
\text { and adjusted data by working days - O (“Public administration and Defence, } \\
\text { compulsory social security”). Nominal value. }\end{array}$ \\
\hline Price Adjustment & Eurostat, HICP Overall Index - Seasonally and Working day adjusted \\
\hline
\end{tabular}

\section{Appendix 2. Specification of the empirical model by country.}

As it was outlined in section 4, che CVAR can be specified with a constant and a linear trend which can be restricted to lie in the cointegration space or left unrestricted.

In the former case, a restricted constant accounts for a mean of the cointegration relation which is different from zero; a restricted trend is included whenever some of the variables in the system exhibit a linear trend while others do not or have a trend with a different slope, so that possibly the cointegration relation would be trending as well. In the present empirical model, if the hypothesis of wage equalization holds, a trend should not be present in the long-run relations. However, as it is clear from table A2, we had to include a linear trend in the cointegration relation in some countries and for some specific time periods to account for cases when wages in some sectors were indeed growing at higher rates than others. While it is not realistic that a trend is present over longer periods, we think this is still a good local approximation, while excluding cointegration because of the presence of a trend would be a potentially important information loss.

Table A2. VECM specification.

\begin{tabular}{|l|l|l|}
\hline Country & $\mathrm{n}$ & Model Specification \\
\hline Bulgaria & 1 & Unrestricted constant, no trend, transitory dummies (2001Q4, 2009Q4) \\
\hline Czech Rep. & 2 & Unrestricted Constant, restricted trend, shift in 2004Q3. \\
\hline Estonia & 3 & Unrestricted constant, no trend \\
\hline Hungary & 2 & Unrestricted constant, no trend \\
\hline Latvia & 2 & Unrestricted constant, no trend, shift at 2006Q4. \\
\hline Lithuania & 3 & Unrestricted constant, no trend \\
\hline Poland & 2 & $\begin{array}{l}\text { Unrestricted constant, trend break at 2008Q1. The trend break accounts for a } \\
\text { large increase in the public sector wage bill which occurred throughout the } \\
\text { economic crisis }\end{array}$ \\
\hline Romant The linear term was restricted to zero in both cointegration \\
relations and such restriction could not be rejected (see Table 3).
\end{tabular}

${ }^{18}$ See also: Poland - Public Expenditure review, Vol. I, p. 33 - The World Bank Report No. 52536-PL. 
